STUDIA I ARTYKU乇Y

\title{
Tadeusz Wolsza
}

https://orcid.org/0000-0002-4652-2838

Instytut Historii Polskiej Akademii Nauk

\section{Naukowe fascynacje profesora Jana Molendy}

\begin{abstract}
Abstrakt: Artykuł dotyczy dorobku naukowego jednego z najwybitniejszych polskich badaczy zajmujących się historią polityczną i społeczną przełomu XIX i XX w., ze szczególnym uwzględnieniem dróg wiodących do niepodległości Polski.
\end{abstract}

Słowa kluczowe: niepodległość, orientacje polityczne, ruch ludowy, Wielka Wojna, zabory.

Abstract: Article is devoted to the scholarly achievement of one of the most outstanding Polish historians specialising in the political and social history of the late nineteenth and early twentieth centuries, with particular emphasis put on the paths leading to the independence of Poland.

Key w or ds: independence, political orientations, people's movement, Great War, partitions.

Profesor Jan Molenda (ur. 1930 r.) jest rozpoznawalny w obecnej chwili jako jeden z najwybitniejszych w Polsce specjalistów zajmujących się historią ruchu ludowego, dziejów polskiej irredenty niepodległościowej oraz I wojny światowej. Po ukończeniu szkoły średniej w Łańcucie studiował historię na Uniwersytecie Warszawskim w latach 1949-1954. Tu przygotował pod kierunkiem prof. dr Żanny Kormanowej pracę magisterską pt. „Walki chłopów w rewolucji 1905-1907 na terenie guberni warszawskiej”. Biorąc pod uwagę, że obszerny fragment pracy (pt. Carat $i$ klasy posiadajace $w$ walce $z$ rewolucja 1905-1907 r. na wsi polskiej) ujrzał światło dzienne na łamach „Przeglądu Historycznego" w 1955 r., można bez cienia wątpliwości skonstatować 
wyjątkowo udany debiut naukowy. Jan Molenda po uzyskaniu magisterium rozpoczą pracę w Instytucie Historycznym Uniwersytetu Warszawskiego na stanowisku asystenta, potem zaś po obronie pracy doktorskiej (pt. „Polskie Stronnictwo Ludowe w Królestwie Polskim 1915-1918”) jako adiunkt. Doktorat pod tym samym tytułem ukazał się drukiem w 1965 r. Oprócz wymienionej monografii, z zakresu dziejów ruchu ludowego i historii chłopów, opublikował kilka innych ważnych studiów i artykułów, jak np.: Masy chtopskie i ruch ludowy w czasie wojny 1914-1918, w: Ruch robotniczy $i$ ludowy $w$ latach 1914-1923, Warszawa 1960 (wyd. 2 popr., 1961) oraz Antyokupacyjne wystapienia chtopów $w$ Królestwie Polskim w zwiazku z uktadem brzeskim z 9 lutego 1918 r. i rola w nich Polskiego Stronnictwa Ludowego, „Roczniki z Dziejów Ruchu Ludowego" (1963, nr 3). Jak można przypuszczać, zainteresowanie historia ruchu ludowego i chłopów wynikało z dwóch powodów. Po pierwsze, Jan Molenda urodził się w rodzinie chłopskiej (wieś Kasina koło Łańcuta) $\mathrm{z}$ tradycjami aktywnej działalności w strukturach organizacji ludowych. Po drugie, zagadnienia dotyczące aktywności politycznej chłopów w Królestwie Polskim na przełomie XIX i XX stulecia oraz ich udział w walkach na rzecz niepodległości nie były jeszcze przedmiotem szczegółowych badań.

$\mathrm{Na}$ początku lat sześćdziesiątych, wspólnie z Jerzym Holzerem, przygotował jedną z najważniejszych ówcześnie monografii poświęconych historii Polski w XX stuleciu, która została wydana na krajowym rynku księgarskim. Mam tu na myśli pracę Polska w pierwszej wojnie światowej (Warszawa 1963). Książka doczekała się kolejnych edycji w 1967 r. i 1973 r. Godne podkreślenia jest to, iż Autorzy w następnych wydaniach dokonali cennych uzupełnień. Zresztą zwrócili uwagę na ten aspekt zagadnienia. W wydaniu drugim rozbudowali fragmenty dotyczace sprawy polskiej na arenie międzynarodowej oraz ruchów masowych w mieście i na wsi, z uwzględnieniem rozwoju oświaty i działalności organizacji oświatowych ${ }^{1}$. Z kolei w wydaniu trzecim dokonali „pewnych korektur do fragmentów dotyczących emigracji polskiej w Rosji oraz sytuacji na Górnym Ślasku”" . Wedle mojej opinii praca wytrzymała próbę czasu do dnia dzisiejszego. Mam tu na myśli m.in. zagadnienia orientacji politycznych w przededniu wybuchu Wielkiej Wojny. Autorzy zwrócili uwagę na orientację na Rosję i Austro-Węgry. „Stronnictwa polskie usiłowały ocenić szanse zwycięstwa poszczególnych stron oraz korzyści, które ewentualnie owe zwycięstwo może przynieść sprawie polskiej lub określonej grupie polskiego społeczeństwa. Charakter, cele i groźba straszliwych dla narodów skutków zbliżającej się wojny nie odgrywały w tych rozważaniach istotnej roli. Uważano, że społeczeństwo polskie w rzeczywisty sposób nie może oddziaływać na rozwój konfliktów europejskich, ale że wojna będzie pożyteczna dla narodu polskiego. Pozostawało więc tylko opowiedzieć się

\footnotetext{
1 J. Holzer, J. Molenda, Polska w pierwszej wojnie światowej, Warszawa 1973, s. 6.

${ }^{2}$ Ibidem, s. 7.
} 
po jednej ze stron"3. Obok szczegółowej analizy sytuacji międzynarodowej i rozwoju wypadków na frontach I wojny mocną stronę pracy stanowiło szczegółowe omówienie działalności niepodległościowych głównych obozów politycznych: narodowych demokratów, piłsudczyków i ludowców, z szerokim uwzględnieniem współpracujaccych z nimi różnego rodzaju organizacji, które podejmowały inicjatywy o charakterze oświatowym, ekonomicznym, samopomocowym, paramilitarnym, niepodległościowym itp. Takie ujęcie problemu stworzyło możliwość, po raz pierwszy w krajowej historiografii, wydobycia z zakamarków naszych dziejów kilkudziesięciu polskich organizacji oświatowych, kulturalnych i ekonomicznych, związanych z kształtowaniem postaw patriotycznych, których celem było odzyskanie niepodległości. Celna wydaje się również uwaga, że „wpływy poszczególnych organizacji chłopskich, obejmujące kilka tysięcy chłopów i inteligencji wiejskiej, aczkolwiek nie były dominujące na wsi, przyczyniły się do istotnej zmiany mapy politycznej wsi Królestwa Polskiego" . Autorzy nie poszli jednak za ciosem i zaniechali kolejnej ważnej konkluzji. Mam tu na myśli doprecyzowanie, że największe wpływy na królewiackiej wsi przed wybuchem I wojny uzyskał jednak obóz wszechpolski (dość tu tylko przywołać np. akcję gminną i dziesiątki innych inicjatyw zaakceptowanych i realizowanych przez chłopów ${ }^{5}$ ).

Jan Molenda, w przywołanej wyżej pracy, przygotował ponadto Słowniczek organizacji politycznych $i$ społecznych, bagatela liczacy sto stron druku. Było to odpowiedzialne wyzwanie. Autor wykonał je z dużą znajomością rzeczy. Przez kilkanaście najbliższych lat ów słowniczek, z prostej przyczyny, traktowano jako encyklopedię z prawdziwego zdarzenia. Dość tu tylko zauważyć, iż to w słowniczku czytelnik mógł odszukać dziesiątki danych i informacji, których nie sposób było namierzyć w różnego rodzaju encyklopediach i leksykonach (np. organizacje oświatowe, samopomocowe, rozbudowane informacje na temat partii i stronnictw politycznych, organizacji paramilitarnych itd.). Po raz pierwszy na łamach tej pracy, w pozytywnym świetle, zostali przedstawieni działacze polityczni skupieni w obozach np. Józefa Piłsudskiego i Romana Dmowskiego. Czytelnik z imienia i nazwiska mógł poznać działaczy pierwszo- i drugoplanowych z poszczególnych partii i stronnictw, którzy wcześniej nie zaistnieli w innych publikacjach (często byli celowo pomijani, stanowiąc zagrożenie dla ponad miarę wypromowanych już, powszechnie nieznanych przedstawicieli Socjaldemokracji Królestwa Polskiego i Litwy lub Polskiej Partii Socjalistycznej-Lewicy). Dla historyków słowniczek nadal spełnia swoją pierwotna rolę. Aczkolwiek Autor zagubił w nim kilka organizacji, które

${ }^{3}$ Ibidem, s. $42-43$.

${ }^{4}$ Ibidem, s. 34-35.

${ }^{5}$ Moim zdaniem liczbę chłopów, którzy podjęli współpracę z narodowymi demokratami, można oszacować na ponad 422 tys. członków różnych organizacji. T. Wolsza, Narodowa Demokracja wobec chłopów w latach 1887-1914. Programy, polityka, działalność, Warszawa 1992, s. 307-308 (aneks 3). 
zasługiwały na wyróżnienie, jak chociażby: Towarzystwo Oświaty Narodowej, Towarzystwo Opieki nad Unitami, Towarzystwo Nauczycieli Szkół Ludowych i Straż, z dziesiątkami działaczy terenowych zaangażowanych w prace społeczno-polityczne i oświatowe ${ }^{6}$.

Jan Molenda z warszawską uczelnią był związany do 1967 r. Następnie rozpoczął pracę w Instytucie Historii Polskiej Akademii Nauk w Warszawie. W nowym miejscu pracy uczestniczył $\mathrm{w}$ przygotowaniu trzeciego i czwartego tomu Historii Polski oraz Historii polskiej klasy robotniczej i Historii chłopów polskich. Najważniejsza wszakże publikację z tego okresu stanowi monografia Pitsudczycy a narodowi demokraci 1908-1918 (Warszawa 1980). Jak sądzę, nie będzie na wyrost kolejne stwierdzenie, że to jedna z najważniejszych publikacji historycznych, bez względu na opisywaną epokę, która ujrzała światło dzienne do 1980 r. Książka zreszta przez cztery lata, od kwietnia 1976 r., była zablokowana przez cenzurę i cierpliwie leżakowała w Redakcji Historycznej Książki i Wiedzy. Jej edycję przyspieszyło powstanie Niezależnego Samorządnego Zwiazku Zawodowego „Solidarność”" . Nie było też dziełem przypadku, iż na bazie tej publikacji Jan Molenda uzyskał habilitację.

Autor, jak wskazuje tytuł monografii, podniósł temat niezwykle ważny, gdyż już od dwudziestolecia międzywojennego historycy toczyli niekończące się dyskusje i polemiki na temat roli tytułowych obozów w sprawie dróg wiodących do niepodległości. Problem wydaje się niebagatelnej wagi. Czy koncepcja Komendanta orientacji na Austro-Węgry była lepszym rozwiązaniem, czy też orientacja na Rosję forsowana przez lidera Narodowej Demokracji wydawała się bardziej skuteczna? Historyk przedstawił szereg argumentów w tej kwestii. Idąc tropem Romana Wapińskiego, podkreślił przede wszystkim, że należy wprowadzić do obiegu pojęcie orientacji na konkretne państwo (Rosję lub Austrię) $)^{8}$. Przez takie właśnie ujęcie zagadnienia zwrócił uwagę, że to polscy politycy skupieni w obozie wszechpolskim lub wokół Józefa Piłsudskiego konsekwentnie realizowali swoje koncepcje wobec zaborców, których finał sprowadzał się do odzyskania niepodległości po 123 latach zaborów. Zaborców zaś wykorzystywali, na ile to oczywiście możliwe, do realizacji nadrzędnego celu. Była to działalność przemyślana i wykonywana etapami.

Wyróżniłbym ponadto rozbudowaną analizę na temat koncepcji Józefa Piłsudskiego, realizowanej przed i po wybuchu Wielkiej Wojny. Jak podaje Autor, warto zwrócić uwagę na dwie broszury Piłsudskiego (wydane pod pseudonimem Z. Mieczysławski) z 1910 r. (Geografie militarna Królestwa Polskiego i Zadania praktyczne rewolucji w zaborze rosyjskim), w których bazując na

\footnotetext{
${ }^{6}$ Szerzej ten wątek rozwinąłem w: ibidem.

${ }^{7}$ J. Molenda, Polska $w$ Wielkiej Wojnie 1914-1918. Kilka refleksji w sprawie stanu badań (cz. II 1939-2014), „Dzieje Najnowsze” 2015, nr 1, s. 177.

${ }^{8}$ R. Wapiński, Narodowa Demokracja 1893-1939. Ze studiów nad dziejami myśli nacjonalistycznej, Wrocław 1980, rozdz. III. „Orientacja na Rosję”.
} 
doświadczeniach z lat 1905-1907, wypracował on taktykę działania na najbliższe lata. Historyk doszedł do wniosku, że Komendant „nie przewidywał jeszcze wówczas (w 1910 r.) ani nawet w 1913 r. użycia swych oddziałów do walk frontowych, lecz wyłącznie do walk powstańczo-partyzanckich" ${ }^{9}$. Nieco później zmodyfikował swoje podejście do tej kluczowej sprawy. Jan Molenda po raz pierwszy w krajowej historiografii w szerszym zakresie zajął się prognozami Józefa Piłsudskiego związanymi z przebiegiem ewentualnego konfliktu zbrojnego, który wisiał na włosku po wojnach bałkańskich. W analizie uwzględnił dwa niezwykle ważne źródła: wywiad, którego Piłsudski udzielił „Kurierowi Litewskiemu” w 1913 r. oraz jego odczyt wygłoszony w lutym 1914 r. w paryskim Towarzystwie Geograficznym. W pierwszym na pytanie, czy ruch wojskowy ma się wysługiwać Austrii, redaktorowi Józefowi Hłasce odpowiedział, że niekoniecznie. „Wystapimy jako siła samodzielna, która przy likwidowaniu wojny, w czasie, kiedy strony będą znużone i wyczerpane, zaważyć będzie mogła na szali” ${ }^{10}$. W dalszej części narracji przywołał prognozy Piłsudskiego związane z przebiegiem ewentualnej wojny. Odwołał się do wspomnień Wiktora Czernowa, który odtworzył treść wykładu Komendanta z Paryża: „Analizując [...] potencjał wojenny wszystkich państw, Piłsudski postawił sprawę na ostrzu noża: jaki będzie przebieg i czyim zwycięstwem zakończy się wojna? Odpowiedź jego brzmiała: zwycięstwo «pójdzie z Zachodu na Wschód». Co to znaczy? To znaczy, że Rosja będzie pobita przez Austrię i Niemcy, a te z kolei będa pobite przez siły angielsko-francuskie (lub angielsko-amerykańsko-francuskie). Wschodnia Europa poniesie klęskę od Europy centralnej, a centralna z kolei od zachodniej. To pokazuje Polakom kierunek działania"11. Jak nietrudno się domyślić, ustalenia Jana Molendy wywołały reakcję innych historyków, którym była bliska sprawa taktyki działania Józefa Piłsudskiego w przededniu wybuchu wojny oraz po jej rozpoczęciu. Tym bardziej że nieco wcześniej inny znany badacz biografii Józefa Piłsudskiego $\mathrm{w}$ ogóle pominął $\mathrm{w}$ analizie ten ważny aspekt zagadnienia ${ }^{12}$. Natomiast tuż po ukazaniu się książki Jana Molendy rozpoczął dyskusję, przy współudziale Tomasza Nałęcza, w której podał w wątpliwość prawdopodobieństwo postawionych przez Komendanta prognoz ${ }^{13}$. Inni historycy zaakceptowali nowatorska propozycję Profesora Jana Molendy. Wrocławski historyk Włodzimierz Suleja, któremu była bliska sprawa działalności Komendanta w latach I wojny

\footnotetext{
${ }^{9}$ J. Molenda, Pitsudczycy a narodowi demokraci 1908-1918, Warszawa 1980, s. 46.

${ }^{10}$ Ibidem, s. 58.

${ }^{11}$ Ibidem, s. 59.

12 A. Garlicki, U źródet obozu belwederskiego, Warszawa 1979. W tej monografii na próżno poszukiwać informacji na temat odczytu Piłsudskiego w Paryżu i relacji Czernowa. Można jednocześnie mieć pewność, że te sprawy były znane autorowi pracy pt. U źródet obozu belwederskiego.

13 T. Nałęcz, U źródet wielkiego sporu, „Kultura”, 28 IX 1980, nr 39; Szkietkiem i okiem, „Kultura”, 16 XI 1980, nr 46; A. Garlicki, Czucie i wiara, „Kultura”, 16 XI 1980, nr 46.
} 
światowej, dodał do niej kolejny ważny wątek, który nazwał licytacją sprawy polskiej wzwyż ${ }^{14}$. Całą sprawę podsumował natomiast pięć lat później na łamach „Dziejów Najnowszych” niżej podpisany ${ }^{15}$.

Według Jana Molendy prognozy zwiazane z wybuchem i przebiegiem wojny oraz postawą Polaków nie stanowiły kresu koncepcji Józefa Piłsudskiego. W kolejnych widział potrzebę zawieszenia werbunków do Legionów oraz rozwój liczebny konspiracyjnej Polskiej Organizacji Wojskowej, czyli niezależnej wobec zaborców siły wojskowej. Te inicjatywy oraz kryzys przysięgowy doprowadziły do internowania Komendanta w niemieckiej twierdzy. Cała taktykę działania wobec zaborców emisariusze Piłsudskiego zreferowali politykom francuskim i brytyjskim.

Historyk z nie mniejszą szczegółowością omówił rozwój koncepcji przygotowanych przez liderów obozu narodowodemokratycznego. Do grona czołowych polityków celnie zaliczył m.in. Zygmunta Balickiego, Romana Dmowskiego, Jerzego Gościckiego, Stanisława Grabskiego, Jana Harusewicza, Józefa Hłaskę, Stanisława Kozickiego, Mieczysława Niklewicza, Antoniego Sadzewicza, Zygmunta Wasilewskiego, Bohdana Wasiutyńskiego, Maurycego Zamoyskiego, Jerzego Zdziechowskiego oraz „bezpartyjnego” Władysława Grabskiego. Zauważył ponadto, że „część tych polityków z Dmowskim na czele, zwłaszcza od 1916 r., zaczęła przenosić się do Europy zachodniej: do Szwajcarii, Francji i Wielkiej Brytanii, gdzie wraz z przebywającymi tam już polskimi politykami prokoalicyjnymi rozszerzali stopniowo działalność polityczna. Odtąd też politycy przebywajacy w Europie zachodniej stanowili coraz bardziej wpływowy ośrodek kierowniczy dla swych organizacji działających w Rosji i na ziemiach polskich" ${ }^{16}$. Jeśli zaś chodzi o działalność na ziemiach polskich, to obóz wszechpolski był zaangażowany przede wszystkim w rozwój instytucji oświatowych, ekonomicznych, samopomocowych, charytatywnych i samorządowych. Mogę od siebie dodać, że zaangażowanie w działalność na rzecz społeczeństwa obywatelskiego, realizowane w zaborze rosyjskim zarówno przed, jak i w trakcie wojny, zaowocowało po wojnie. Sprawdzianem popularności dla działaczy związanych z obozem wszechpolskim, którzy w latach 1914-1918 pracowali w swoim najbliższym otoczeniu, były oczywiście wybory parlamentarne.

${ }^{14}$ W. Suleja, Spór o ksztatt aktywizmu: Piłsudski a Sikorski w latach I wojny światowej, w: Polska myśl polityczna XIX i XX wieku, t. V: W kręgu twórców myśli politycznej, red. H. Zieliński, Wrocław 1983, s. 166 i n. Autor przywołał i rozwinął w tym wypadku artykuł S. Skwarczyńskiego pt. Licytacja sprawy polskiej wzwyż. Postawy i metody działania Józefa Piłsudskiego w okresie pierwszej wojny, „Niepodległość” (Londyn-Nowy Jork) 1972, t. VIII. Por. też: W. Suleja, Józef Pitsudski, Wrocław 1995, s. 139-172, rozdz. „Licytacja”. Najnowsze wydanie: idem, Mundur na nim szary... Rzecz o Józefie Piłsudskim (1867-1935), Warszawa 2018.

${ }_{15}$ T. Wolsza, W sprawie prognoz Józefa Piłsudskiego dotyczacych przebiegu I wojny światowej, „Dzieje Najnowsze” 1985, nr 3-4, s. 159-166.

16 J. Molenda, Pitsudczycy..., s. 223. 
W konfrontacji z legionistami oraz działaczami uwikłanymi w różne inicjatywy niepodległościowe, którzy po odzyskaniu niepodległości wrócili w rodzinne strony i wystartowali w wyborach z list partii socjalistycznej i ludowej, kandydaci obozu wszechpolskiego wyszli zwycięsko. Dla lokalnego wyborcy ważniejsze okazały się kontakty codzienne w gminie niż bliżej im nieznane lub zbyt skromnie rozpropagowane na prowincji bitwy i potyczki legionistów.

Praca Jana Molendy, wydana w 1980 r., wytrzymała próbę czasu i na stałe weszła do obiegu naukowego. Z drobnych zagadnień, które można byłoby rozwinaćc, należy wskazać znaczenie bitwy pod Kostiuchnówką dla podniesienia roli i znaczenia legionistów. Polacy nie tylko uchronili wówczas Niemców i Austriaków od większej klęski. Postawą w walce zyskali uznanie generałów z państw centralnych. Nie było więc dziełem przypadku, że Niemcy i Austriacy chcieli mieć po swojej stronie milion takich właśnie zaprawionych w boju żołnierzy. Tak przynajmniej oceniali możliwości mobilizacyjne Polaków w 1916 r. Kostiuchnówka to niewątpliwie cezura podejścia polityków z państw centralnych do spraw polskich ${ }^{17}$.

Miałem już okazję nadmienić, iż dzieje ruchu ludowego i historia chłopów w Polsce stanowią bodajże najważniejsze zagadnienia badawcze w naukowej biografii Jana Molendy. Podsumowaniem owych zainteresowań była niewątpliwie praca pt. Chłopi, naród, niepodległość. Kształtowanie sie postaw narodowych i obywatelskich chłopów w Galicji i Królestwie Polskim w przededniu odrodzenia Polski (Warszawa 1999). Tę publikację, obok tematu, wyróżniaja wykorzystane źródła. Mam tu na myśli listy i publicystykę, wyłowione przez Autora z kilkunastu czasopism, jak np. „Przyjaciel Ludu”, „Gazeta Ludowa”, „Piast”, „Zaranie”, „Polska Ludowa” i „Wyzwolenie” oraz ze zbiorów archiwalnych. Zauważyłem jedynie absencję kilku czasopism endeckich zaadresowanych m.in. do chłopów, w których dziesiątki korespondencji w okresie ożywienia społeczno-politycznego w Królestwie Polskim na początku XX w. stanowiły ważny dział zaadresowany do wiejskiego odbiorcy. Upominam się zwłaszcza o „Polaka”.

Autor zdefiniował instytucje i wydarzenia, które jego zdaniem wywierały największy wpływ na kształtowanie świadomości narodowej i obywatelskiej chłopów. Uważam, że to nowatorska i oryginalna propozycja, poparta

17 P. Waingertner, Wołyński klucz do niepodległości. Bitwa pod Kostiuchnówka 4-6 lipca 1916 roku i pamięć o niej, „Dzieje Najnowsze” 2017, nr 2, s. 39-51. Autor oceniając bitwę, skonstatował: „W ten sposób postawa legionistów pod Kostiuchnówką stała się dla niemieckich polityków i wojskowych istotnym argumentem na rzecz choćby częściowego zaspokojenia polskich aspiracji niepodległościowych. Ceną za zgodę Niemiec na powstanie związanego z Berlinem państwa polskiego miało być utworzenie polskich sił zbrojnych, wspierających armię niemiecką i austro-węgierska. Działanie to wpisywało się zarazem w niemiecka koncepcję tzw. Mitteleuropy [...]. Uznać można zatem, iż postawa zaprezentowana przez legionistów pod Kostiuchnówką przyczyniła się w istotny sposób do wydania cztery miesiące później przez władców Niemiec i Austro-Węgier Aktu 5 listopada zapowiadającego powstanie Królestwa Polskiego". Ibidem, s. 49. 
wieloletnimi badaniami nie tylko na temat chłopów w Królestwie Polskim i Galicji, ale i emigracji zarobkowej (kilka publikacji pomieszczonych np. w „Przeglądzie Polonijnym”, „Przeglądzie Historycznym”, „The Polish Review” oraz w pracach zbiorowych). Historyk dostrzegł pięć czynników. Najwyżej ocenił działalność wiejskich organizacji i instytucji, w tym szkoły elementarnej, szkoły rolniczej, samorządu terytorialnego, parafii i lokalnego księdza. Na niższym poziomie wskazał obchody rocznic powstań narodowych (1794 i 1863 r.), współorganizowanych przez duchowieństwo, nauczycieli i wiejskie organizacje. Jako trzecie wymienił stronnictwa ruchu ludowego i ich organy prasowe upowszechniające idee niepodległościowe i wizję demokratycznej Polski. Następnie wskazał na emigrację zarobkowa poza granicami ziem polskich oraz służbę wojskową na frontach I wojny światowej. W końcu przywołał reprezentacje polityczno-narodowe oraz organizacje i formacje wojskowe $^{18}$. Jan Molenda wśród kilkudziesięciu organizacji oświatowych, z których niektóre działalność rozpoczęły już w latach siedemdziesiątych XIX stulecia lub później, wyróżnił Koła Oświaty Ludowej i Towarzystwo Oświaty Narodowej. Natomiast jeśli chodzi o stronnictwa ludowe, to wskazał na Polski Związek Ludowy i Związek Młodej Polski Ludowej, który wpisał do swojego statutu hasło walki o niepodległość. Nie stanowi też zaskoczenia to, że przypomniał osiagnięcia działającej w zaborze rosyjskim Polskiej Macierzy Szkolnej, przez której szeregi przeszło 116341 członków. Wedle jego opinii podobna rolę w zaborze austriackim spełniło Towarzystwo Szkoły Ludowej. Cele szkół były identyczne bez względu na ich zaborową lokalizację. Wszystkim przyświecała idea, którą mocno wyeksponował Wincenty Witos: „aby uczeń wychodził ze szkoły Polakiem”. Obok edukacji historyk ważną rolę w procesie kształtowania świadomości narodowej i patriotycznej chłopów przypisał kultywowanym rocznicom narodowym. Bazując na zawartości czasopism ruchu ludowego, wskazał na najważniejsze rocznice: kościuszkowska (170 uroczystości), powstanie 1863 r. (101), bitwa pod Grunwaldem (85), Konstytucję 3 maja (74) i powstanie 1831 r. (37). Dodał do tego rocznice związane z działalnościa pisarską: Marii Konopnickiej, Adama Mickiewicza, Juliusza Słowackiego, Stanisława Wyspiańskiego i Henryka Sienkiewicza. Zauważył również, iż pomiędzy zaborami występowała duża dysproporcja pod względem liczby obchodów: w Galicji - 472 i w Królestwie Polskim - 142. Sprawę wytłumaczył odmiennymi warunkami politycznymi w zaborze austriackim i rosyjskim. Jeśli chodzi o Królestwo Polskie, to podkreślił, że władze carskie konsekwentnie nie udzielały Polakom zgody na oficjalne obchody rocznic narodowych. Wyjatek stanowiło odsłonięcie pomnika Adama Mickiewicza w Warszawie w 1898 r. Natomiast rocznica Konstytucji 3 maja była obchodzona konspiracyjnie od $1891 \mathrm{r}$.

18 J. Molenda, Chtopi, naród, niepodlegtość. Kształtowanie się postaw narodowych i obywatelskich chłopów w Galicji i Królestwie Polskim w przededniu odrodzenia Polski, Warszawa 1999, s. 39-40. 
Jan Molenda w rozważaniach uwzględnił jeszcze jeden ważny wątek traktujący o kształtowaniu wzorców zachowań polityczno-narodowych i obywatelskich. Dolną cezurę stanowią „Szkice programowe” z 1886 r., w których pojawił się pierwszy zarys koncepcji idei niepodległościowej. Autorzy dokumentu uznali za najważniejsze, nie tracąc z pola widzenia niepodległej Polski, uobywatelnienie chłopów, zrównanie ich w prawach z innymi grupami społecznymi, demokratyzację panujących stosunków i zaszczepienie im zasad demokratycznego działania oraz obywatelskiego angażowania się w sprawy publiczne ${ }^{19}$. Hasła odwołujące się do potrzeby odzyskania niepodległości były obecne w programach i publicystyce prasowej niemal przez cały okres opisywany przez historyka. Jan Molenda poczynił interesujące spostrzeżenie w sprawie skuteczności realizowanej na wsi propagandy. Jeśli chodzi o nasilenie haseł niepodległościowych w przekazie prasowym, to wymienił lata 1905-1906, 1908, 1912 i 1914-1918. Przy czym zauważył, że zwiększeniu liczby publikacji na ten temat nie towarzyszył wzrost czytelników czy też członków stronnictw ludowych. Wyjątek stanowiły jego zdaniem lata 19171919. W tym miejscu też, chcąc pokazać skalę zjawiska, podał dane na temat nakładów poszczególnych tytułów. „Przyjaciel Ludu” pomiędzy 1901 i 1907 r. zwiększył liczbę prenumeratorów z 1380 do 17 tys. egzemplarzy. „Polska” (organ Narodowego Związku Chłopskiego) podniosła nakład w pierwszym roku wojny z 10 do 15 tys. „Chłopska Sprawa” (organ Związku Chłopskiego) ukazywała się w nakładzie 2500 egzemplarzy. Znane powszechnie „Zaranie” wychodziło w nakładzie 8 tys. egzemplarzy, chociaż liczbę stałych czytelników redakcja oszacowała na 5 tys. Jeśli natomiast chodzi o liczbę członków Polskiego Stronnictwa Ludowego (PSL) w Królestwie Polskim, to pomiędzy 1915 i 1919 r. wzrosła z 5 do ok. 50 tys. W Galicji główny organ prasowy PSL - „Piast” w 1914 r. ukazywał się w nakładzie 8 tys. egzemplarzy. Trzy lata później doszedł do 70-80 tys. egzemplarzy. W konkluzji Profesor podkreślił: „Z uwagi na masowe angażowanie się tych chłopów-ludowców w działalność niepodległościową nie tylko własnych partii, ale i reprezentacji polityczno-narodowych oraz Polskiej Organizacji Wojskowej, fakt przynależności do stronnictw ruchu ludowego można beż większych zastrzeżeń traktować już wówczas jako dowód świadomości narodowej włościan. W końcowych latach I wojny światowej i w początkach II Rzeczypospolitej około 100000 chłopów-ludowców już nie tylko pozostawało w kręgu propagandy niepodległościowej ruchu ludowego, POW i związanych z nimi reprezentacji polityczno-narodowych, ale też aktywnie uczestniczyło w antyokupacyjnych i antyzaborowych wystapieniach, w walkach o zrzucenie obcego panowania i zabezpieczeniu granic rodzacej się II Rzeczypospolitej"20. W wydanym rok później studium pt. Chtopi polscy w 1914 roku historyk rozwinął kilka ważnych zagadnień,

19 Ibidem, s. 242.

${ }^{20}$ Ibidem, s. 263-264. 
które wcześniej li tylko zamarkował w innych publikacjach. Sprawa dotyczyła np. zniszczeń wojennych na polskiej wsi w latach Wielkiej Wojny oraz - co szczególnie chciałbym wyróżnić - roli kobiet i młodzieży w kierowaniu gospodarstwami pod nieobecność mężczyzn, którzy odbywali służbę wojskowa albo w armiach zaborczych, albo w Legionach. W konkluzji podkreślił, iż „funkcje kierowania gospodarstwami rodzinnymi i reprezentowania ich na zewnątrz przejmowały przeważnie żony zmobilizowanych”. Następnie dodał, że w wykonywanie typowo męskich prac, zwłaszcza w obchodzeniu się zaprzęgiem, orce, koszeniu traw i zbóż, były zaangażowane starsze dzieci, chłopcy w wieku od 9 do 17 lat, niepodlegajacy poborowi. Gdy zabrakło chłopców, tę rolę pełniły starsze dziewczęta ${ }^{21}$. Badacz historii chłopów nie mniejsze znaczenie przypisał samopomocy sasiedzkiej, która rozwijała się na dużą skalę. Jan Molenda poruszył ponadto problem pomocy charytatywnej dla ludności Królestwa Polskiego, zdefiniowanej jako „wieś dla dzieci”, „o polskie dzieci” i „lud polski w Warszawie”. Środki zebrane w wyniku tej akcji zostały skierowane na dożywianie rodzin chłopskich. W zaborze pruskim inicjatywy pomocowe pilotowała redakcja „Gazety Grudziądzkiej”, ukazująca się w nakładzie 60 tys. egzemplarzy ${ }^{22}$.

Monografia pt. Chtopi, naród, niepodległość. Ksztattowanie się postaw narodowych i obywatelskich chłopów w Galicji i Królestwie Polskim w przededniu odrodzenia Polski oraz cały dorobek naukowy stanowiły podstawę wniosku Rady Naukowej Instytutu Historii PAN o nadanie Janowi Molendzie tytułu profesora. Procedura zakończyła się zasłużoną nominacją w 2000 r., po blisko 45 latach aktywnej działalność naukowej mierzonej kilkoma wybitnymi monografiami oraz osiagnięciami w zakresie kształcenia młodej kadry naukowej.

O ile książkę pt. Chtopi, naród, niepodlegtość. Ksztattowanie się postaw narodowych i obywatelskich chtopów w Galicji i Królestwie Polskim w przededniu odrodzenia Polski można traktować jako podsumowanie badań na temat chłopów, o tyle dwie kolejne publikacje uznałbym za ukoronowanie zainteresowań związanych z Wielka Wojna. W stulecie wybuchu wojny prestiżowe czasopismo Instytutu Historii PAN „Dzieje Najnowsze” opublikowało kilkanaście przeglądów badań na temat konfliktu zbrojnego w latach 1914-1918, który post factum został nazwany I wojna światowa. Zaproszeni do współpracy wybitni badacze z kilku ośrodków naukowych w kraju: Jan Molenda, Iwona Sakowicz i Jacek Tebinka, Małgorzata Gmurczyk-Wrońska, Halina Parafianowicz, Mariusz Wołos, Arkadiusz Stempin, Jerzy Gaul, Krzysztof Buchowski i Bogusław Kosel, Mirosław Dymarski oraz Jan Jacek Bruski przedstawili wnikliwe rozważania na temat historiografii: polskiej, brytyjskiej, francuskiej, amerykańskiej, rosyjskiej, niemieckiej, austriackiej, czeskiej, litewskiej,

${ }^{21}$ J. Molenda, Chłopi polscy w 1914 roku, „Dzieje Najnowsze” 2004, nr 3, s. 125.

${ }^{22}$ Ibidem, s. 128. 
serbskiej, bułgarskiej i ukraińskiej ${ }^{23}$. Jan Molenda w obszernym tekście omówił krajowy i emigracyjny stan badań nad Wielką Wojna, począwszy od pierwszych publikacji na temat Legionów, które ujrzały światło dzienne już w 1915 r., skończywszy zaś na opublikowanych w 2014 r. W imponujących rozważaniach pomieścił szereg cennych informacji źródłoznawczych. Poprzestając na liczbach, można stwierdzić, że badaczowi udało się ustalić 567 broszur poświęconych tematyce pierwszowojennej ${ }^{24}$. Wskazał np. na bezcenne źródło, za które uznał $Z$ Dokumentów Chwili, liczące 110 tomików dokumentów. Przywołał wydawnictwo źródeł z 1915 r., pt. Legiony Polskie, zawierające 67 dokumentów z różnej proweniencji. Dodał do tego Dokumenty Naczelnego Komitetu Narodowego z 1917 r. z 216 dokumentami z lat wojny. W swoich rozważaniach uwzględnił kilkadziesiąt tytułów prasowych z okresu 1914-1918 i z dwudziestolecia międzywojennego, podnoszących tematykę Wielkiej Wojny. W końcu zwrócił uwagę na dyskusję, która przewinęła się przez „Niepodległość” - prestiżowe wydawnictwo Instytutu Badania Najnowszej Historii Polski. Następnie zajął się dorobkiem z lat 1939-2014. Podkreślił, że II wojna światowa spowodowała rozproszenie i zniszczenie zasobów archiwalnych, z tak dużym trudem zebranych w latach 1918-1939 i ulokowanych m.in. w Instytucie Badania Najnowszej Historii Polski. Profesor nadmienił, że bezpowrotnie uległy zniszczeniu np. kolekcja Związku Walki Czynnej oraz gotowa praca na jego temat, przygotowana na bazie dokumentacji zebranej przez Wandę Kiedrzyńską. Z okresu powojennego przypomniał historię pracy przygotowanej przez profesorów Witolda Kulę i Henryka Wereszyckiego. Pierwszy z nich napisał Historie gospodarcza Polski $w$ dobie popowstaniowej 1864-1918 (Warszawa 1947), drugi - Historie polityczna Polski w dobie popowstaniowej 1864-1918 (Warszawa 1948). Następnie omówił przebieg kariery naukowej Henryka Wereszyckiego oraz kilku innych pracowników (np. Wacława Lipińskiego, Stanisława Płoskiego) Instytutu Pamięci Narodowej i Instytutu Historii Najnowszej. Podręcznik Henryka Wereszyckiego został ostatecznie wycofany i skierowany na przemiał. Autorowi Historii politycznej Polski w dobie popowstaniowej Ministerstwo Szkolnictwa Wyższego nie zatwierdziło habilitacji i zakazało w ogóle jej druku²5. Jan Molenda przypomniał również kulisy powstania dwóch tomów Historii Polski (w tym zawierającego omówienie I wojny światowej). W dalszej części analizy zwrócił uwagę na główne kierunki badań dotyczących Wielkiej Wojny od lat pięćdziesiątych do osiemdziesiątych XX w. Zauważył, iż zdominowały je sprawy poświęcone problematyce politycznej (np. dotyczące obozów politycznych skupionych

${ }^{23}$ „Dzieje Najnowsze” 2014, nr 3, s. 57-185; „Dzieje Najnowsze” 2015, nr 1, s. 167-190; „Dzieje Najnowsze” 2015, nr 2, s. 127-142.

${ }^{24}$ J. Molenda, Polska $w$ Wielkiej Wojnie 1914-1918. Kilka refleksji w sprawie stanu badań (cz. I 1914-1939), „Dzieje Najnowsze” 2014, nr 3, s. 58.

${ }^{25}$ Idem, Polska $w$ Wielkiej Wojnie 1914-1918. Kilka refleksji $w$ sprawie stanu badań (cz. II 1939-2014)..., s. 172. 
wokół Romana Dmowskiego i Józefa Piłsudskiego) oraz militarnej (polski czyn zbrojny). Po 1989 r. wyróżnił rozwój biografistyki, w tym kilka udanych prac na temat: Józefa Piłsudskiego (np. Włodzimierza Sulei) i Romana Dmowskiego (Krzysztofa Kawalca) oraz m.in. Kazimierza Sosnkowskiego, Walerego Sławka, Jędrzeja Moraczewskiego, Edwarda Rydza-Śmigłego, Michała Sokolnickiego, Kazimierza Świtalskiego, Bolesława Wieniawy-Długoszowskiego, Bogusława Miedzińskiego, Juliusza Poniatowskiego, Tadeusza Hołówki, Gustawa Orlicza-Dreszera, Stanisława Grabskiego i Stanisława Kozickiego. Pragnę w tym miejscu wskazać, iż Janowi Molendzie również była bliska biografistyka. Przygotował m.in. kilka biogramów do Polskiego Stownika Biograficznego (m.in. Stanisława Najmoły, Zygmunta Nowickiego, Saturnina Osińskiego, Józefa Ostrowskiego, Antoniego Piątkowskiego, Andrzeja Pluty, Juliusza Poniatowskiego, Franciszka Radziwiłła, Michała Rękasa, Wojciecha Hilarego Rostworowskiego i Wiktora Skołyszewskiego).

Ostatnią publikację, którą zamierzam wyróżnić z dorobku Jana Molendy, stanowi pięciotomowa Wielka Wojna $w$ polskiej korespondencji zatrzymanej przez cenzurę austro-wegierskq. Materiaty polskich grup cenzury z lat 1914-1918 (t. I-V, Warszawa 2018). Praca ujrzała światło dzienne w serii wydawniczej Instytutu Historii PAN „Metamorfozy społeczne” i do druku przygotował ją zespół w składzie: Paweł Brudek, Jan Molenda i Jerzy Z. Pająk. Kolejny kamień milowy w krajowej historiografii, moim zdaniem już trzeci, którego autorem lub współautorem był Jan Molenda. To źródło o kapitalnym znaczeniu przy opisaniu życia codziennego w Legionach. Materiały zebrane i opublikowane przez zespół pod kierunkiem Jana Molendy dają możliwość uzupełnienia listy tych, którzy przeszli przez Legiony (Stownik biograficzny legionistów pod redakcją Janusza Ciska). Dostrzegam również kolejną zaletę. Mam tu na myśli ważną dokumentację, która uszczegółowi politykę dowództwa austro-węgierskiego wobec Polaków służących w armii zaborczej.

Profesor Jan Molenda w całej karierze naukowej był wierny kilku zagadnieniom: historii chłopów i ruchu ludowego, sprawie polskiej w latach Wielkiej Wojny oraz myśli politycznej najważniejszych obozów politycznych w drugiej połowie XIX i w pierwszych latach XX stulecia. Z tego zakresu opublikował kilka monografii, studiów i artykułów, które na stałe wprowadziły historyka do grona najwybitniejszych badaczy w skali ogólnopolskiej.

\section{Streszczenie}

Profesor Jan Molenda był naukowo związany z Instytutem Historycznym Uniwersytetu Warszawskiego, Instytutem Historii Polskiej Akademii Nauk w Warszawie oraz Instytutem Historii Uniwersytetu Jana Kochanowskiego w Kielcach. Badacze i recenzenci zajmujący się XIX i XX w. wyróżnili w jego dorobku naukowym kilka ważnych publikacji, które można zaliczyć do kamieni milowych krajowej historiografii. Tematycznie dorobek prof. Molendy dotyczy historii chłopów i ruchu ludowego na ziemiach polskich przed odzyskaniem niepodległości w 1918 r., dróg wiodących do niepodległości oraz I wojny światowej z uwzględnieniem 
czynu legionowego. Do najważniejszych prac Profesora należy zaliczyć: Polska $w$ pierwszej wojnie światowej (współautor Jerzy Holzer), Warszawa 1973; Piłsudczycy a narodowi demokraci 1908-1918, Warszawa 1980; Chtopi, naród, niepodlegtość. Ksztattowanie sie postaw narodowych i obywatelskich chłopów w Galicji i Królestwie Polskim w przededniu odrodzenia Polski, Warszawa 1999. W 2018 r. Jan Molenda wraz z zespołem wydał drukiem ważne źródło dotyczące I wojny światowej, pt. Wielka Wojna w polskiej korespondencji zatrzymanej przez cenzure austro-węgierska. Materiaty polskich grup cenzury z lat 1914-1918 (t. I-V).

\section{Scientific Fascinations of Professor Jan Molenda}

Professor Jan Molenda was professionally associated with the Institute of History of the University of Warsaw, the Institute of History of the Polish Academy of Sciences in Warsaw, and the Institute of History of the Jan Kochanowski University in Kielce. Scholars and reviewers interested in the history of the nineteenth and twentieth centuries have distinguished in his scientific achievements several vital publications that can be regarded as the milestones of national historiography. Thematically, Prof. Molenda's scholarly achievements are devoted to the history of peasants and the peasants' movement on Polish lands before Poland regained independence in 1918, the paths leading to the Polish independence, and World War I, including the Polish Legions. The most important texts include: Polska $w$ pierwszej wojnie światowej (Poland in World War I [co-author Jerzy Holzer], Warsaw, 1973); Pitsudczycy a narodowi demokraci 1908-1918 (Pilsudskiites and the National Democrats, 1908-18, Warsaw, 1980); Chłopi, naród, niepodległość. Kształtowanie się postaw narodowych i obywatelskich chłopów w Galicji i Królestwie Polskim w przededniu odrodzenia Polski (Peasants, Nation, Independence. The Shaping of National and Civic Attitudes of Peasants in Galicia and the Kingdom of Poland on the Eve of Poland's Rebirth, Warsaw, 1999). In 2018, Jan Molenda and his team published a vital source on World War I, entitled: Wielka Wojna w polskiej korespondencji zatrzymanej przez cenzurę austro-wegierska. Materiaty polskich grup cenzury z lat 1914-1918 (The Great War in Polish Correspondence Intercepted by the Austro-Hungarian Censorship. Materials of Polish Censorship Groups from 1914-18; vol. I-V).

\section{Bibliografia}

Garlicki A., Czucie i wiara, „Kultura”, 16 XI 1980, nr 46.

Garlicki A., U źródet obozu belwederskiego, Warszawa 1979.

Holzer J., Molenda J., Polska w pierwszej wojnie światowej, Warszawa 1973.

Molenda J., Chtopi polscy w 1914 roku, „Dzieje Najnowsze” 2004, nr 3.

Molenda J., Chłopi, naród, niepodległość. Ksztattowanie się postaw narodowych i obywatelskich chłopów w Galicji i Królestwie Polskim w przededniu odrodzenia Polski, Warszawa 1999.

Molenda J., Pitsudczycy a narodowi demokraci 1908-1918, Warszawa 1980.

Molenda J., Polska $w$ Wielkiej Wojnie 1914-1918. Kilka refleksji w sprawie stanu badań (cz. I 1914-1939), „Dzieje Najnowsze” 2014, nr 3.

Molenda J., Polska $w$ Wielkiej Wojnie 1914-1918. Kilka refleksji w sprawie stanu badań (cz. II 1939-2014), „Dzieje Najnowsze” 2015, nr 1.

Nałęcz T., Szkietkiem i okiem, „Kultura”, 16 XI 1980, nr 46.

Nałęcz T., U źródet wielkiego sporu, „Kultura”, 28 IX 1980, nr 39.

Suleja W., Józef Pitsudski, Wrocław 1995.

Suleja W., Spór o ksztatt aktywizmu: Pitsudski a Sikorski w latach I wojny światowej, w: Polska myśl polityczna XIX $i$ XX wieku, t. V: W kręu twórców myśli politycznej, red. H. Zieliński, Wrocław 1983. 
Waingertner P., Wołyński klucz do niepodległości. Bitwa pod Kostiuchnówka 4-6 lipca 1916 roku i pamięć o niej, „Dzieje Najnowsze” 2017, nr 2.

Wapiński R., Narodowa Demokracja 1893-1939. Ze studiów nad dziejami myśli nacjonalistycznej, Wrocław 1980.

Wolsza T., Narodowa Demokracja wobec chłopów w latach 1887-1914. Programy, polityka, działalność, Warszawa 1992.

Wolsza T., W sprawie prognoz Józefa Pitsudskiego dotyczacych przebiegu I wojny światowej, „Dzieje Najnowsze” 1985, nr 3-4.

Tadeusz Wolsza - prof. dr hab., pracownik Instytutu Historii PAN w Warszawie i Wydziału Nauk o Polityce i Administracji Uniwersytetu Kazimierza Wielkiego w Bydgoszczy. Prowadzi badania naukowe na temat polskiej emigracji powojennej w Wielkiej Brytanii, więziennictwa w powojennej Polsce, zbrodni katyńskiej oraz historii sportu. E-mail: mwolsza@wp.pl.

Tadeusz Wolsza - Prof. dr. hab., employee of the Tadeusz Manteuffel Institute of History of the Polish Academy of Sciences in Warsaw, and the Faculty of Political Sciences and Public Administration of the Kazimierz Wielki University in Bydgoszcz. He conducts scholarly research into the Polish post-war emigration in Great Britain, prison system in the post-war Poland, the Katyn crime, and history of sports. E-mail: mwolsza@wp.pl. 